\title{
Beliefs about knowledge sebagai pemediasi antara pengaruh personality factor terhadap academic performance
}

\author{
Alfiati Silfi ${ }^{1^{*}}$ \\ ${ }^{1,2}$ Fakultas Ekonomi dan Bisnis Universitas Riau \\ *Correspondent email : alfiatisilfi@gmail.com
}

Abstract. The objective of the study is to investigate the influence between personality factors towards Academic performance with Beliefs about knowledge as Mediated. Personality factors consist of five dimensions of personality known as The Big Five Personality. Then, the academic Performance uses Grade Point Average (GPA). The sample in this study is from 250 accounting students at several uiversities in Indonesia. Data were analyzed with SPSS by regression analysis to examine the influence of Personality factors towards Academic Performance. The result shows that all hypotheses are eaccepted.

Keywords: Personaliuty factors, Academic performance, Beliefs about knowledge, The big five personality, Grade point Average

\section{PENDAHULUAN}

Perkembangan dunia saat ini telah semakin maju dan menghendaki seluruh elemen organisasi mencari peluang dan posisi strategis serta keunggulan bersaing. Seluruh profesi yang ada turut berpartisipasi dalam berbagai bisnis dunia. Salah satu elemen penting untuk membawa organisasi mencapai tujuan tersebut adalah memiliki sumber daya manusia yang ahli dan terampil pada bidangnya, tidak terkecuali profesi di bidang akuntansi.

Mulai tahun 2012, Indonesia mulai mengadopsi secara penuh standar laporan keuangan internasional (IFRS). Munculnya IFRS tak bisa lepas dari perkembangan global, terutama yang terjadi pada pasar modal. Perkembangan teknologi informasi (IT) di lingkungan pasar yang terjadi begitu cepat dengan sendirinya berdampak pada aspek di pasar modal. Perkembangan yang mengglobal dengan sendirinya menuntut adanya satu standar akuntansi yang dibutuhkan baik oleh pasar modal atau lembaga yang memiliki agency problem. Yang menghubungkan jarak antara principle dan agent adalah informasi, dalam hal ini yang dimaksud adalah informasi seperti asset, resources dan lainnya yang berhubungan dengan kondisi perusahaan yang dikelola oleh agent.

Untuk menghasilkan informasi tentang keadaan suatu perusahaan yang dapat memenuhi kebutuhan berbagai pihak menjadikan profesi akuntan semakin memegang peranan penting. Akuntan memegang peranan penting pada seluruh aspek aktivitas bisnis. Akuntan bertanggungjawab terhadap proses pengendalian dan merancang pembuatan informasi keuangan yang akurat suatu perusahaan, menjadi konsultan untuk perkembangan bisnis, keuangan dan lain sebagainya. Pekerjaan seorang akuntan tidak hanya terbatas pada penyusunan dan pelaporan keuangan, dan informasi bisnis tetapi juga berperan dalam memberikan bantuan untuk internal perusahaan dalam proses perencanaan, pengendalian dan pengambilan keputusan.

Yang menjadi pertanyaan penting untuk saat ini adalah bagaimanakah kesiapan profesi akuntan di Indonesia dalam memberikan kemampuan yang berkualitas dan kompeten di bidang akuntansi? Bagaimana kesiapan dunia pendidikan akuntansi dalam menghasilkan akuntan yang berkualitas dan kompeten ? Pada tahun 1989 The Big accounting firms (Jones,1995) menyatakan bahwa lulus menjadi akuntan public bukanlah suatu tujuan tetapi yang terpenting adalah bagaimana seorang yang berprofesi sebagai akuntan memiliki kemampuan dalam menganalisis dan berpikir konseptual dalam menghadapi tantangan dan peluang bagi suatu perusahaan.

Jika dibandingkan dengan beberapa Negara di kawasan ASEAN, jumlah akuntan public di Indosesia sangat jauh tertinggal. Padahal berdasarkan UU 40/2007 tentang Perseroan Terbatas, perusahaan yang memiliki omzet minimal Rp 50 milyar wajib diaudit oleh Akuntan public. Sampai saat 


\section{SYNERGY}

Vol 1, No 2, Oktober 2021, p. 53-57

Jurnal Bisnis dan Manajemen

e-ISSN : 2777-0346 | p-ISSN : 2777-0354

ini jumlah akuntan public di Indonesai hanya mencapai 1.000 orang (dengan jumlah penduduk 240 juta). Padahal Singapura yang merupakan Negara kecil dan Filipina memiliki lebih dari 20.000 akuntan public. Saat ini Indonesia hanya mampu mencetak 60 orang akuntan public setiap tahun,sementara Singapura dan Filipina sudah mencapai 1.000 orang akuntan public per tahun.

Era globalisasi menuntut setiap negara memiliki kemampuan dalam mengatasi persaingan. Untuk itu semua profesi yang ada akan terlibat dalam kancah persaingan tersebut. Akuntan sebagai salah satu profesi yang sangat diperlukan dalam segala aspek dan kehidupan, juga mengalami perkembangan sesuai dengan kemajuan ilmu dan teknologi. Namun di Indonesia perkembangan profesi akuntan tidak semaju perkembangan di Negara lain khususnya asia tenggara. Hal ini tidak sebanding dengan jumlah penduduknya yang sangat besar dibandingkan Negara lain.

Salah satu alat ukur untuk melihat kemampuan mahasiswa adalah Academic performance. Academic performance yang dimiliki mahasiswa dapat mencerminkan kemampuan mereka dalam menguasai bidang ilmu yang telah mereka peroleh di perguruan tinggi. Sehingga untuk bisa memasuki profesi akuntan salah satu syarat yang harus dipenuhi adalah Academic performance yang bagus. Memiliki Academic performance yang bagus akan dianggap lebih memiliki penguasaan yang lebih baik dalam bidang akuntansi. Sehingga Academic performance ini menjadi focus penting untuk diteliti. Selanjutnya perlu ditelusuri faktor faktor apa yang dapat mempengaruhi Academic performance dan keterkaitan antara factor- factor tersebut dengan Academic performance.

Untuk mengkaji factor-faktor apa saja yang dapat mempengaruhi kinerja akademik bisa kita lihat dari segi psikologi. Karena factor psikologi berasal dari pribadi manusia yang dapat mendorong dan memotivasi manusia untuk melakukan sesuatu yang yang diinginkan dan diharapkannya. Demikian juga dengan Academic performance, maka mahasiswa akan terdorong untuk meningkatkan academic performance karena factor-faktor psikologi yang melekat pada diri mereka seperti : sifat, sikap dan keyakinan yang mereka miliki dari lahir hingga dewasa.

Dalam penelitian ini factor psikologi yang diperkirakan dapat mempengaruhi kinerja akadamik adalah factor personality, factor keyakinan terhadap pengetahuan dan pendekatan pembelajaran. Ketiga factor ini dapat tumbuh dan berkembang pada jiwa dan diri seseorang. Sehingga dalam dunia pendidikan factor-faktor ini diharapkan dapat dikembangkan dengan baik pada masing-masing individu. Lebih khusus lagi pada profesi akuntan yang membutuhkan calon akuntan yang memiliki kemampuan yang lebih untuk menganalisis berbagai macam masalah yang terjadi.

\section{METODE PENELITIAN}

\section{Populasi dan Sampel}

Populasi dalam penelitian ini adalah mahasiswa akuntansi tingkat akhir pada universitas di beberapa propinsi yang ada di Indonesia. Universitas yang dijadikan populasi adalah beberapa universitas negeri dan swasta di beberapa kota dan ibu kota propinsi di Indonesia. Adapun universitas yang menjadi sampel dalam penelitian ini adalah universitas negeri dan swasta pada tiga level akreditasi yaitu akreditasi A, B dan C. Level akreditasi ini ditentukan oleh Badan akreditasi Nasional pada tahun 2015. Jumlah universitas untuk masing-masing level akreditasi terdiri dari 5 universitas yang masing-masingnya terdiri dari 50 orang mahasiswa akuntansi.

Jumlah kuesioner yang dikirimkan sebanyak 50 eksemplar untuk mahasisa jurusan akuntansi di 15 universitas diatas. Adapun mahasiswa strata satu akuntansi yang dipilih sebagai sampel adalah mahasiswa semester 6 (enam) yaitu mahasiswa tingkat terakhir yang telah banyak menempuh mata kuliah akuntansi.

Data untuk keperluan penelitian ini dikumpulkan melalui dua bentuk yaitu : kuesioner dan Indeks Prestasi kumulatif. Kuesioner yang disampaikan kepada responden disertai dengan surat permohonan untuk menjadi responden dan penjelasan mengenai petunjuk pengisian. Penjelasan petunjuk pengisian kuesioner dibuat sederhana dan sejelas mungkin sehingga lengkap.

\section{Operasional Variabel}

Survey dilakukan untuk menaksir pendekatan pembelajaran, keyakinan terhadap pengetahuan dan factor personality yang dimiliki dan digunakan oleh mahasiswa akuntansi dan lulusan akuntansi (caloncalon akuntan).

Secara garis besar variabel dalam penelitian ini ada 3 yaitu :

Academic Performance adalah prestasi yang dimiliki seseorang dalam proses belajar, dalam hal ini diwakili oleh kumpulan nilai seorang mahasiswa di akhir semester.

Untuk mengukur variable academic performance adalah dengan menggunakan Grade Point Average (GPA) yang diperoleh sampai dengan akhir semester. GPA ini ditunjukkan dengan kriteria nilai 
yang berkisar dari 2 sampai 4. Biasanya GPA yang berkisar antara 2,00 - 2,5 (sangat buruk), 2,5 - 2,9 (sedang) dan 3-3,5 (Baik) dan 3,5-4 (Sangat Baik).

\section{Personality Factors}

Personality Factors adalah kuesioner yang dikenal dengan The Big Five Personality yang dikembangkan oleh Costa and Robert (1995) yang dikenal dengan NEO-PI-R. Seluruh instrument diatas terdiri atas lima skala likert yang dimulai dari 5 (sangat setuju), 4 (setuju), 3 (netral), 2 (tidak setuju) dan 1 (sangat tidak setuju).

\section{Beliefs about knowledge}

Beliefs about knowledge adalah keyakinan yang dimiliki seseorang dalam mempelajari suatu ilmu pengetahuan dalam proses belajar.

Instrumen Beliefs adalah kuesioner yang dikembangkan oleh Schommer $(1990,1993)$. Kuesioner ini dimulai darng menggunakan lima skala likert yang dimulai dari 5 (sangat setuju), 4 (setuju),3 (netral), 2 (tidak setuju) dan 1 (sangat tidak setuju).

\section{Teknik data Analisis}

Data yang telah dikumpulkan dianalisis dengan alat analisis korelasi dan regresi serta path analysis dengan bantuan Program SPSS.

\section{HASIL DAN PEMBAHASAN}

\section{Uji Hipotesis}

Pengujian hipotesis dimaksudkan untuk menguji hipotesis-hipotesis yang telah diajukan pada Bab II. Pengujian hipotesis ini dilakukan dengan menganalisis nilai C.R (Critical Ratio) dan nilai $P$ value lalu dibandingkan dengan batasan statistik yang telah disyaratkan, yaitu di atas 2,0 untuk nilai CR dan di bawah 0,05 untuk nilai $P$ value. Apabila hasil olah data menunjukkan nilai yang memenuhi syarat tersebut, maka hipotesis penelitian yang diajukan dapat diterima. Selanjutnya pembahasan mengenai pengujian hipotesis akan dilakukan secara bertahap sesuai dengan urutan hipotesis yang telah diajukan. Berikut adalah rangkuman hasil estimasi parameter dari analisis yang telah dilakukan seperti berikut :

\section{Pengaruh Personality factors terhadap Academic Performance.}

Hipotesis yang diuji adalah :

$\mathrm{H}_{0}$ : Tidak ada pengaruh antara Personality factor terhadap academic performance

$\mathrm{H}_{1}$ : Terdapat pengaruh antara Personality factor terhadap academic performance

Kriteria Uji : Tolak Ho jika t-hitung lebih besar dari t-tabel atau to $\mathrm{t}_{0}$-tabel, dengan:

$\mathrm{dk}=\mathrm{n}-\mathrm{k}-1$ maka derajat kebebasan $=750-3-1=746$, dan nilai $\mathrm{t}=\frac{r \times i \sqrt{n-k-1}}{\sqrt{1-(r x i)^{2}}}$

Tabel 1. Hasil Uji Parsial Variabel Personality factor terhadap academic performance

\begin{tabular}{ccccc}
\hline Struktural & $\begin{array}{c}\text { Koefisien } \\
\text { Jalur }\end{array}$ & t Hitung & $\mathrm{t}$ Tabel & \multicolumn{1}{c}{ Kesimpulan } \\
\hline$\rho_{Y X 1}$ & 0,228 & 5.501 & 1.963 & $\begin{array}{l}\text { Ho ditolak, Terdapat pengaruh antara } \\
\text { Personality factor terhadap academic } \\
\text { performance }\end{array}$ \\
\hline
\end{tabular}

Untuk koefisien jalur Personality factor terhadap academic performance $(\mathrm{Y})$ sebesar 0,228 , diperoleh t-hitung sebesar 5.501 dengan mengambil taraf signifikan sebesar 5\%, maka nilai t-tabel sebesar 1.963 sehingga dikarenakan t-hitung= 5.501 lebih besar dari 1.963 maka Ho ditolak dengan kata lain Terdapat pengaruh antara Personality factor terhadap academic performance.

\section{Pengaruh Beliefs about knowledge terhadap Academic Performance.}

Hipotesis yang diuji adalah :

$\mathrm{H}_{0}$ : Tidak ada pengaruh antara Beliefs about knowledge terhadap academic performance

$\mathrm{H}_{1}$ : Terdapat pengaruh antara Beliefs about knowledge terhadap academic performance

Kriteria Uji : Tolak Ho jika t-hitung lebih besar dari t-tabel atau $\mathrm{t}_{0}>\mathrm{t}$-tabel, dengan:

$$
\mathrm{dk}=\mathrm{n}-\mathrm{k}-1 \text { maka derajat kebebasan=750-3-1=746, dan } \quad \text { nilai } \mathrm{t}=\frac{r \times i \sqrt{n-k-1}}{\sqrt{1-(r x i)^{2}}}
$$


Tabel 2. Hasil Uji Parsial Variabel Beliefs about knowledge Terhadap terhadap academic performance

\begin{tabular}{ccccc}
\hline Struktural & $\begin{array}{c}\text { Koefisien } \\
\text { Jalur }\end{array}$ & t Hitung & t Tabel & \multicolumn{1}{c}{ Kesimpulan } \\
\hline$\rho_{Y X 1}$ & 0,183 & 4.763 & 1.963 & $\begin{array}{l}\text { Ho ditolak, Terdapat pengaruh antara } \\
\text { Beliefs about knowledge terhadap } \\
\text { academic performance }\end{array}$ \\
\hline
\end{tabular}

Untuk koefisien jalur Beliefs about knowledge terhadap academic performance sebesar 0,183, diperoleh t-hitung sebesar 4.763 dengan mengambil taraf signifikan sebesar 5\%, maka nilai t-tabel sebesar 1.963 sehingga dikarenakan t-hitung= 4.763 lebih besar dari 1.963 maka Ho ditolak dengan kata lain Terdapat pengaruh antara Beliefs about knowledge terhadap academic performance

Pengaruh Personality factors terhadap Academic Performance melalui Beliefs about knowledge

Untuk menganalisis hubungan kaulitas dan pengaruh antara Personality factors terhadap Academic Performance melalui Beliefs about knowledge, digunakan suatu metode analisis. Berdasarkan pada hasil kuesioner yang telah disebarkan dibantu dengan program SPSS.

Tabel berikut mengungkapkan adanya pengaruh langsung dan tidak langsung dari variabel Personality factors terhadap Academic Performance melalui Beliefs about knowledge

Tabe1 3. Pengaruh Langsung, Tidak Langsung dan Total Pengaruh

\begin{tabular}{llll}
\hline Variabel & \multicolumn{3}{l}{ Personality factors } \\
\cline { 2 - 4 } & Langsung & $\begin{array}{l}\text { Tidak } \\
\text { Langsung }\end{array}$ & Total \\
$\begin{array}{l}\text { Beliefs about } \\
\text { knowledge }\end{array}$ & 0.59 & 0.00 & 0.59 \\
$\begin{array}{l}\text { Academic } \\
\text { Performance }\end{array}$ & 0.06 & 0.05 & 0.11 \\
\hline
\end{tabular}

Personality factors memiliki pengaruh langsung terhadap Beliefs about knowledge sebesar 0.59 lebih besar dibandingkan dengan pengaruh tidak langsung terhadap Beliefs about knowledge sebesar 0.00 . Kemudian, Personality factors memiliki pengaruh total terhadap Beliefs about knowledge sebesar 0.06 lebih besar dari pengaruh tidak langsung terhadap academic performance 0,05 . Pengaruh total Personality factors terhadap Academic Performance sebesar 0.59. Selanjutnya pengaruh total personality factors terhadap academic performance adalah 0,11 . Hasik ini menunjukkan bahwa personality factors memberikan pengaruh lebih besar terhadap beliefs about knowledge daripada academic performance. Sehingga hasil penelitian ini menunjukkan bahwa personality factors secara sigifikan mempengaruhi beliefs about knowledge dan demikian juga beliefs about knowledge signifikan mempengaruhi academic performance. Dengan demikian dapat dikatakan bahwa beliefs about knowledge memediasi pengaruh antara personality factors terhadap academic performance.

\section{KESIMPULAN}

Dari hasil uji yang telah dilakukan maka penelitian ini menghasilkan beberapa penemuan yaitu :

1. Pengujian hipotesis pertama diterima yaitu Personality factors berpengaruh terhadap Academic Performance. Hasil penelitian ini mendukung penelitian Duff et.al (2003), Hasil penelitian ini juga mendukung penelitian

2. Pengujian hipotesis kedua diterima yaitu Beliefs about knowledge berpengaruh terhadap Academic Performance. Hasil penelitian ini mendukung penelitian Phillips (1998), Cano (2005) dan Phan (2006).

3. Pengujian hipotesis ketiga diterima yaitu Personality factors dimediasi oleh Beliefs knowledge dalam hubungannya dengan Academic performance

\section{UCAPAN TERIMAKASIH}

Terimakasih kepada semua pihak yang telah membantu penelitian ini. 


\section{DAFTAR PUSTAKA}

Cano, F. (2005). Epistemological Beliefs and Approaches to learning: Their change through secondary school and their influence on academic performance. British Journal of Educational Psychology 75, 203-221.

Costa, P.T.Jr. \& McRae, R.R. (1995). Domains and Facets : hierarchical personality assessment using the revised NEO personality inventory. Journal of Personality Assessment64,21-50.

Duff, A., Boyle., E, Dunleavy, K., \& Ferguson, J. (2004).The Relationship between Personality, Approach to learning and Academic Performance.Personality and Individual Differences36,1907-1 920.

Jones \&Davidson, R.A. (1995).Relationship between level of formal reasoning and students'performance in accounting examinations.Contemporary Accounting Research12, 163-181.

Phillips, F.(1998). Accounting students'associating beliefs about knowledge : Associating Performance with Underlying Belief Dimensions .Issues In AccountingEducation. Issues in Accounting Education (Vol. 13, No. 1) 113-126.

Schommer, M. (1990).Effects of beliefs about the nature of knowledge on comprehension.Journal of Educational Psychology82,498-504. 